\title{
Grupo de Estudios Afro-Hispánicos (GEAH), B.P. 2007, Kisangani
}

AN Afro-Hispanic Studies Group was established at a meeting in March 1970 in Kisangani, République du Congo: the Director is Profeśsor Luis Beltrán and the Secretary-General Professor Manuel de Esteve-Sabater. The aim is to bring together Spanish and HispanicAmerican Africanists and African Hispanists and institutions with related scholarly and research interests. Its activities will include the encouragement and facilitation of research, the establishment of a documentation centre and the publication of a bulletin and monographs: it will act as an intermediary in the collection, exchange, and dissemination of information and publications and collaborate with other centres with particular reference to problems resulting from processes of modernization, and will hold conferences on subjects within its field. The official languages of the group are English, French, Spanish, and Swahili. Its first publication issued in April 1970, ' La Cultura Hispánica en Africa Negra', gives an account of Hispanic studies in Black African Universities and outlines proposals for a cultural policy; publications on African Studies in Hispanic America and a Directory of Spanish-speaking Africanists are in preparation.

\section{Traditional Attitudes, Beliefs, and Practices Relevant to Family Planning (in East Africa)}

THIs project has been initiated by the Ford Foundation, which finances it, with the approval of the Kenya Ministry of Health, the Institute of African Studies of the University of Nairobi, and the Family Planning Association of Kenya. Dr. Angela Molnos, Ford Foundation project specialist, is directing the survey and is seeking the co-operation of social anthropologists with field experience in East Africa as well as family-planning field-workers.

The objectives of the survey are twofold. One aim is to find out whether there are traditional attitudes, beliefs, and practices of East African peoples on which modern familyplanning communication can be based. If so, an attempt will be made to reformulate arguments and create a new African image of family planning as having at least some roots in cultural traditions instead of being an utterly alien, ' imported ' practice. The other aim is to process the findings and present them in a source book for those seeking first-hand information for use in family planning communications in East Africa. The book will contain social anthropological material as well as information from family-planning field-workers.

The formulation of the reseatch questions will be based on the analysis of the available attitude surveys and on a preliminary inquiry among family-planning field-workers. Among the phases and methods to be used are the following:

I. Selection of those ethnic groups on which the social anthropological part of the survey will concentrate. Compilation of a comprehensive bibliography on traditional attitudes, beliefs and practices of the selected ethnic groups relevant to family planning (values attached to children; fertility; the nature of contraceptive practices, etc.). Preparation of an annotated address list of social anthropologists who have first-hand knowledge of the selected ethnic groups.

2. Survey among family-planning field-workers about their experiences with patients, potential users of family planning, drop-outs, opponents, etc.

3. Evaluation of the survey among family-planning field-workers.

4. Extracting from the social anthropological literature all available answers to the research questions.

5. Survey among social anthropological experts with first-hand knowledge of the selected ethnic groups. 